УДК 543.2

\title{
ИЗУЧЕНИЕ КИСЛОТНОСТИ ОСАДКОВ ПОТЕНЦИОМЕТРИЧЕСКИМ МЕТОДОМ
}

\author{
Шинкаренко Софья Андреевна \\ студент \\ ФГБОУ ВО РГАУ-МСХА им. К.А. Тимирязева \\ Воршева Александра Владимировна \\ ассистент кафедры химии \\ ФГБОУ ВО РГАУ-МСХА имени К.А. Тимирязева \\ н.с. ФНЦ «ВИК им. В.Р. Вильямса»
}

\begin{abstract}
Аннотация: осадки, вызванные загрязнением окружающей среды, являются глобальной экологической проблемой. Частота их появления с каждым годом возрастает, что беспокоит не только научное сообщество, но и общественность. Ядовитые осадки негативно влияют на организм человека, флору и фауну планеты. Прогулявшись под кислотным дождем, можно столкнуться с сердечными и легочными патологиями.
\end{abstract}

Ключевые слова: осадки, кислотные дожди, окружающая среда, экология, $\mathrm{pH}$.

\section{STUDY OF THE ACIDITY OF PRECIPITATION BY THE POTENTIOMETRIC METHOD}

\section{Shinkarenko Sophia Andreevna Vorsheva Alexandra Vladimirovna}

\begin{abstract}
: precipitation caused by environmental pollution is a global environmental problem. The frequency of their occurrence increases every year, which worries not only the scientific community, but also the public. Poisonous precipitation negatively affects the human body, flora and fauna of the planet. Walking in acid rain, you can encounter cardiac and pulmonary pathologies.
\end{abstract}

Key words: precipitation, acid rain, environment, ecology, $\mathrm{pH}$. 
Сегодня уже не редкость осадки на $2-3$ pH ниже нормы. Проблема наиболее характерна для стран с развитой тяжелой промышленностью: Китая, США, России. Фиксировались случаи, когда на территории этих стран в результате интенсивной работы предприятий металлургии выпадали осадки, $\mathrm{pH}$ которых составлял всего $2-3$ единицы. Под ударом находятся и соседние страны, ведь отравленные облака могут перенестись ветрами куда угодно.

Кислотными называют не только дожди, но и прочие виды осадков (град, снег, туман), в составе которых присутствуют кислоты. Нормальная дождевая вода не должна иметь $\mathrm{pH}$ ниже 5,6. Если значение ниже, то говорят о кислой воде. Основными компонентами кислотных дождей являются серные и азотные оксиды, хлористый водород и некоторые органические соединения. Особо токсичным, приносящим наибольший вред биосфере компонентом, является диоксид серы.

Токсичные вещества, попадая в воздух, в атмосфере контактируют с углекислотой, водой, солнечной радиацией, образуя молекулы кислот. С мельчайшими каплями воды кислоты устремляются в верхние атмосферные слои, где образуются облака, из которых на землю выпадают кислотные дожди.

Кислотосодержащие осадки существовали и негативно влияли на экосистему планеты всегда, но раньше они имели исключительно природное происхождение. А сегодня основными причинами возникновения кислотных дождей являются антропогенные факторы, такие как, например, токсичные выбросы предприятий тяжелой промышленности; выхлопные газы транспорта; добыча и переработка угля, нефти, газа; сжигание любых видов органического топлива.

Отрицательных последствий выпадения кислотных дождей множество. Ядовитые осадки приводят к:

- нарушению экобаланса водоемов;

- окислению почвы;

- угнетению жизнеспособности растений;

- ухудшению здоровья людей;

- разрушению построек, архитектурных объектов.

Стоит отметить влияние кислотных дождей на человека. У людей, вышедших в дождливую погоду без зонта, могут обостриться симптомы аллергии или астмы, появиться злокачественные новообразования. Особенно чувствительны к атмосферным токсинам маленькие дети. 
Цель исследования: изучить кислотность осадков (снега) на территории г. Москвы (Тимирязевский р-н).

Место отбора проб: г. Москва, остановка общественного транспорта Тимирязевская академия, вокруг памятника В.Р. Вильямса.

Метод исследования - потенциометрический, прибор - pH-метр-иономер «Экотест-2000».

Методика исследования:

1. Образцы снега отбираются в чистый стаканчик;

2. Ежедневно отбирается по 10 проб;

3. Отмечается вид осадков, направление и скорость ветра.

Результаты наблюдений представлены в таблице 1.

Таблица 1

\section{Результаты наблюдений}

\begin{tabular}{|c|c|c|c|c|c|c|c|c|c|}
\hline $\begin{array}{l}\text { Дата, } \\
\text { март } \\
2021 \\
\end{array}$ & $\begin{array}{c}\text { Вид } \\
\text { осадков }\end{array}$ & $\begin{array}{c}\text { Направление } \\
\text { ветра }\end{array}$ & $\begin{array}{c}\text { Скорость } \\
\text { ветра }\end{array}$ & $\begin{array}{c}\mathrm{pH} \\
\text { осадков }\end{array}$ & $\begin{array}{l}\text { Дата, } \\
\text { март } \\
2021 \\
\end{array}$ & $\begin{array}{c}\text { Вид } \\
\text { осадков }\end{array}$ & $\begin{array}{c}\text { Направление } \\
\text { ветра }\end{array}$ & $\begin{array}{c}\text { Скорость } \\
\text { ветра }\end{array}$ & $\begin{array}{c}\mathrm{pH} \\
\text { осадков }\end{array}$ \\
\hline 1 & - & 3 & $1 \mathrm{M} / \mathrm{c}$ & - & 11 & - & 3 & $1 \mathrm{~m} / \mathrm{c}$ & - \\
\hline 2 & - & C3 & $2 \mathrm{M} / \mathrm{C}$ & - & 12 & - & 1 & $3 \mathrm{~m} / \mathrm{c}$ & $\cdot$ \\
\hline 3 & - & 3 & $2 \mathrm{~m} / \mathrm{c}$ & . & 13 & CHer & 10 & $2 \mathrm{~m} / \mathrm{c}$ & 7,10 \\
\hline 4 & - & $\mathrm{C} 3$ & $1 \mathrm{~m} / \mathrm{c}$ & - & 14 & CHer & 10 & $2 \mathrm{~m} / \mathrm{c}$ & 7,15 \\
\hline 5 & - & $\mathrm{C3}$ & $3 \mathrm{~m} / \mathrm{c}$ & - & 15 & - & 10 & $1 \mathrm{~m} / \mathrm{c}$ & - \\
\hline 6 & - & 3 & $1 \mathrm{~m} / \mathrm{c}$ & - & 16 & Дождь & $B$ & $1 \mathrm{~m} / \mathrm{c}$ & 6,95 \\
\hline 7 & Снег & 3 & $2 \mathrm{~m} / \mathrm{c}$ & 7,45 & 17 & CHer & & $1 \mathrm{~m} / \mathrm{c}$ & 6,90 \\
\hline 8 & CHer & $\mathrm{CB}$ & $2 \mathrm{~m} / \mathrm{c}$ & 7,20 & 18 & CHer & $\mathrm{C3}$ & $2 \mathrm{~m} / \mathrm{c}$ & 7,05 \\
\hline 9 & - & $\mathrm{C3}$ & $2 \mathrm{M} / \mathrm{C}$ & - & 19 & - & $\mathrm{C3}$ & $1 \mathrm{~m} / \mathrm{c}$ & - \\
\hline 10 & - & C & $2 \mathrm{~m} / \mathrm{c}$ & - & 20 & - & $\mathrm{C} 3$ & $1 \mathrm{~m} / \mathrm{c}$ & - \\
\hline
\end{tabular}

Измерялся $\mathrm{pH}$ не только свежевыпавшего снега, но и ежедневные его изменения с целью выявления действия на него антропогенных факторов (таблица 2).

Таблица 2

\section{Измерение рН снега}

\begin{tabular}{|c|c|}
\hline Дата & pH cнera \\
\hline 9.03 .21 & 6,95 \\
\hline 10.03 .21 & 6,89 \\
\hline 11.03 .21 & 6,89 \\
\hline 12.03 .21 & 6,57 \\
\hline
\end{tabular}


Результаты исследований:

1. В период с 01.03.21 по 20.03.21 кислотных осадков на территории г. Москвы (Тимирязевский р-н) не выявлено.

2. Под действием антропогенных фактор (выхлопных газов от автотранспорта и др.) происходит подкисление снега, что доказывает необходимость уборки и вывоза снега вблизи дорог.

3. Рекомендуем не разрешать детям и подросткам играть в снежки вблизи дорог.

\section{Список литературы}

1. Воронова М.М., Серганова М.А., Воршева А.В. Физико-химические свойства городских почв и пути их улучшения. В сборнике: Стратегический потенциал молодежной науки. Сборник статей Международного научно-исследовательского конкурса. Петрозаводск, 2021. С. 113-117.

2. Латыпова В.З., Яковлева О.Г. и др. Динамика ионного состава и кислотные свойства атмосферных осадков Приказанского региона (Республика Татарстан). Ученые записки Казанского государственного университета. Серия: Естественные науки. 2005. Т. 147. № 3. С. 141-150.

3. Муха Д.Э., Кондратьев И.И., Мезенцева Л.И. Трансграничный перенос кислотных осадков циклонами Восточной Азии на юг Дальнего Востока России. География и природные ресурсы. 2012. № 2. С. 21-26.

4. Романенко М.Е. Экологические проблемы кислотных осадков. Металлогения древних и современных океанов. 2011. № 1. С. 304-305.

5. Семак В.А., Гуляева К.Н. Чувствительность сельскохозяйственных культур к выпадению кислотных осадков. Russian Agricultural Science Review. 2015. T. 5. № 5-1. С. 157-159.

6. Соловьёв Е.В., Харитон В. Кислотные осадки. Сравнительная характеристика кислотности в различных регионах. В сборнике: Инновации в медицине и фармации - 2018. Сборник материалов дистанционной научно-практической конференции студентов и молодых ученых. Белорусский государственный медицинский университет. 2018. С. 807-811. 